きっかけについて述べる。

13. 交替勤務と睡眠に関する意識調査一加齢にともな う変化一

\author{
○斉藤政彦・榊原一恵 \\ (大同特殊鋼 星崎診療所)
}

某鉄鋼会社従業員で交替勤務を経験したことのある男 性 763 名に「交替勤務と睡眠」に関する意識調查を実施 し，主に年齢別で分析検討を行った。その結果，睡眠時 間については「昼勤時の夜間睡眠時間」の方が「夜勤時 の昼間睡眠時間」に比較して長かった，さらに「昼勤時 の夜の睡眠時間」は年齢が進むにつれて長くなったが, 逆に「夜勤時の昼の睡眠時間」は年齢とともに短くなっ た. 夜勤時の昼間の睡眠については「良く眠れる」と答 えた人の割合が年齢とともに隇少し，一方で「酒を飲ん で寝る」が中高年者で高かった，病気を抱えている人の 割合は年歯とともに増加し，50 代では $44 \%$ の人が何ら かの病気を治療中であった. 50 歳以上の夜勤の是非に 関する意識は「健康上の問題がなければしても良い」と 肯定的な人の割合が若い人で少なく, 逆に 40 代 50 代で 多いという結果が得られた。

\section{4. 睡眠時間帯の変化と生体機能}

○武山英麿，井谷 徹 (名市大・医・衛生)

昼間睡眠から夜間睡眠へ生活パターンを変化させたと きの自律神経活動, 唾液コルチゾール, 体温, 自覚症状 の結果などを実験的にスケジュール設定し検討した．実 験第 1,2 日目は深夜 $0: 00$ から $8 ： 00$ まで，3〜 5 日目 は, 8：00から 16:00 まで実験室で生活させた。この間, 2 時間毎に上記測定項目の他，記憶テストと反応時間の 測定を行った．本報告では1名の結果について事例報告 する，副交感神経活動の指標である HF は，時間帯に関 わらず睡眠時に対応して上昇し，覚醒時には低い值で推 移した，交感神経活動の指標である $\mathrm{LH} / \mathrm{HF}$ 比は, $\mathrm{HF}$ 值と相反する変動を示した。体温，コルチゾールは，ほ ぼ本来の概日リズムを示した，反応時間は，昼間睡眠か ら夜間睡眠への移行による差は見られなかったが，記憶 テストの成績が，昼間睡眠 2 日間より昼間睡眠で低くな る傾向にあった．この結果から夜間睡眠から昼間睡眠へ の移行が，より高次の中枢神経機能に影響を及ぼす可能 性が推察されるが，今後例数を増やしてさらに検討する 必要性があると思われる.

\section{5. 看護婦の勤務状況と労働負担に関する質問紙調查}

○鈴村初子・武山英磨・城 憲秀・井谷 徹

(名市大・医・衛生)

愛知県内 2 大学病院の看護婦が働く職場の状況等に焦
点をあて, 勤務場所の違いによる仕事の特徴と疲労状況， Burnout 状況との関わりをみることを目的に調查をし た.

仕事の特徽は内科・外科病棟では，仕事は多忙で不規 則であるがやりがいがあり，外来は忙しさや難しさは少 ないが補助的で雑用が多い。蓄積的疲労徴候は，内科病 棟・ICUは身体の疲れからのへばりが外科病棟では身 体的側面での疲労がみられた. Burnoutスコアから ICU では情緒疲幣, 離人化得点が高く, 自己成就感も内科・ 外科病棟に比べて低く, 問題が感じられた。結論として, 内科・外科病棟, ICUに勤務する看護婦は情緒疲弊, 離 人化傾向が外来看護婦に比べて強く，Burnoutに陥る危 険性があると考えられた。

\section{6. 労働者の腰痛の現状とその対策}

加藤 晃・岩井 淳 - 飯田英男

（愛知産業保健推進センター）

131 事業所と 3,944 人の従業員に対するアンケート調 查結果を分析した。調查の基本方針として，7日または それ以上継続した腰痛に重点をおき，数量的表示として 日本整形外科学会の判定基準（JOA スコア）を用いた.

腰痛の始まり打よび経過より, 第 36 回腰痛研究会で 発表した方法を用いて，1型より4型までに分類した。 各型の JOA スコア, 休業率, 男女比, 下肢痛頻度を比 較して，差異を認めた。

腰痛の発生要因について, 事業主㧍よび従業員に同一 項目，同一順序で質問を行った。結果は全体的にはかな り一致していたが，規模別，業種別に比較すると，とく に後者においてところどころに不一致が見られ，その子 防対策に不備が見られた。

4 型について静的要因と動的要因の指摘率を比較し た。結果は急性腰痛の 1 型, 2 型に比べて, 慢性腰痛の 3 型， 4 型において, 静的要因の指摘率が高くなること を認めた。

\section{7. 岐阜県の建設業における労衝衛生管理活動の実態}

井奈波良一・井上眞人・岩田弘敏（岐皁大・医・衛生） 鳥澤重男（岐皁産業保健推進センター）

岐卓県内の建設業の店社主および現場における衛生管 理水準を高める具体的な施策を進めるために役立てるこ とを目的に, 岐阜県内の規模 30 人以上の建設業に属す る事業場を対象として労衝衛生管理活動の実態を明らか にするためのアンケート調查を実施した．建設事業場に 扔ける労㗢安全衛生管理体制の現状を調査した結果, 実 施率が全体で $90 \%$ 以上であった項目は，「定期の健康診 断を実施している」および「緊急連絡網を関係者に周知 している」であった。一方，実施率が全体で $50 \%$ 以下 であった項目は，「産業医の職場巡視を実施している」, 